\title{
A única função do educador é pôr a criança na rua, no mundo
}

\author{
Por Fanny Abramovich
}

Resumo: Nascida em São Paulo e formada em Pedagogia pela Universidade de São Paulo, a professora, jornalista e escritora Fanny Abramovich comemorou 20 anos de carreira em 2009. Lecionou e escreveu livros para crianças, jovens, adultos e professores e foi convidada para levar - seu conhecimento pelo Brasil todo, mexendo mais com teatro-educação e criatividade-educação. Trabalhou anos como jornalista, fazendo crítica de livros para crianças e falando do que se produzia para elas, como brinquedos, discos, teatro. Fez o mesmo tipo de trabalho na televisão. Colaborou com vários jornais e revistas, bem como atuou em consultoria para projetos especialmente criados para crianças e jovens, na área do teatro, da literatura e da educação. Neste Depoimento*, ela conta por que tem valido a pena tudo o que fez na vida.

Palavras-chave: educação, arte-educação, literatura infantojuvenil, jornalismo, teatro.
Abstract: Born in Sao Paulo and holding a bachelor degree in Pedagogy by Universidade de Sao Paulo, the teacher, journalist and writer Fanny Abramovich celebrated her 20 years of career in 2009. She taught and wrote books for children, youth, adults and teachers and was invited to take her knowledge throughout Brazil, dealing with theater-education and creativity-education. She worked for years as a journalist, making criticism of children's books, and speaking of what was produced for them, toys, phonograph records, theater. She made the same kind of work in television. Collaborated with several newspapers and magazines. Acted as consultant for projects specifically designed for children and youth in the areas of theater, literature and education. In this testimonial, she tells why everything she did in life has been worth it.

Keywords: education, art education, children's and youth literature, journalism, theater.

Meu sobrenome não chega a ser um Souza para um não judeu, mas é uma coisa muito comum e quer dizer Filho de Abraão. Nasci no dia 21 de setembro de um ano aí qualquer, faz tempo. Não falo idade nem me peso. O resto, o que quiser... No ano em que nasci, segundo contava a minha avó, era o dia do Ano-Novo judaico, que estava começando, e primeiro dia do ano do Dragão, do qual sou afilhada. Nasci abençoada. Nasci em São Paulo, cresci em São Paulo, comecei a trabalhar em São Paulo.

A minha mãe morreu há quase quarenta anos: Elisa Kauffman Abramovich, uma santa judia. Não era bem santa. Mamãe era comunista, militante. Passou a ser por causa do filho de uma amiga da minha avó que estava sendo caçado pelo Dops ${ }^{1}$. Ficou escondido um ano e meio na casa da vovó; ele aproveitou e fez a cabeça da mamãe. Ela era uma mulher brilhante; fez um desses cursos que 
nem existem mais, de fazer flor. Um belo dia, o Partidão ${ }^{2}$ disse para ela que teria de ser diretora de uma escola judaica progressista - estava iniciando-se -, e ela foi. Era uma educadora muito mais antenada e mais concentrada do que jamais fui. E era vanguarda de vida!! Uma mulher ousada. Fazia de tudo.

A minha avó era derretente. Enquanto minha mãe me empurrava para o mundo, para a vida, minha avó dava o colo. Era muito inteligente, muito bacana. Quando fiz 14 anos, minha mãe virou-se para mim e falou: "Fanny, até 14, normal ter mesada. A partir de amanhã, trabalha e se sustenta, se vira, compre o que quer com o seu dinheiro". Era setembro, o que eu podia fazer? Comecei a dar aulas particulares. Um pouco depois, quando recebi o primeiro salário, deslumbrada, minha avó falou: "Quero 10\% para os meus pobres". "Mas, vovó, sou comunista!" Como se eu soubesse o que estava falando... Ela disse: "Não tenho nada contra o seu comunismo. Mas, para os meus pobres poderem viver, para ficarem vivos, morarem no seu comunismo, têm que comer. Você me dá essa parte". Achei um argumento lógico. Até ela morrer dei essa parte; depois distribuí para outros.

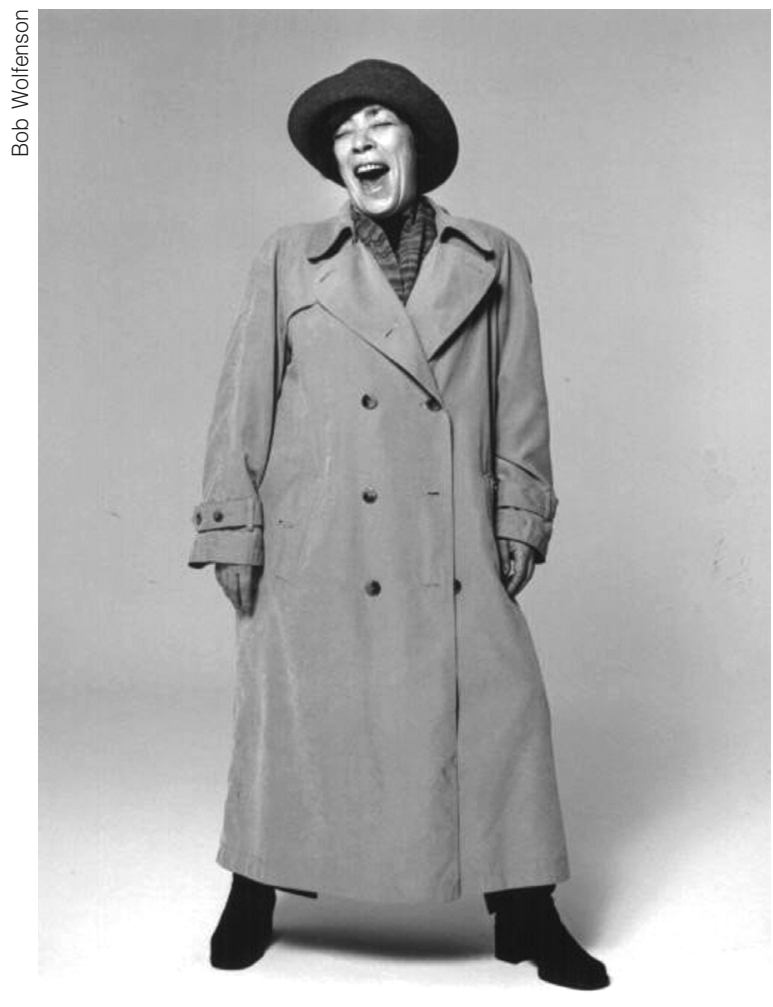

Lenny, eternizada em sua foto mais conhecida.

Meu tio, que ninguém entendia como andava, porque tinha um problema ósseo enorme, era relojoeiro - foi sacação da minha avó ele ir trabalhar com as mãos - e campeão sul-americano de remo, porque seus braços podiam tudo. O Adib Jatene, o doutor, remava junto com o meu tio, e a minha irmã, que é médica, foi aluna do Jatene durante 200 anos, e ele nunca deu a menor pelota para a Irene. Um dia, a Irene falou para ele: "O senhor sabe que remou com o meu tio como seu capitão?". "Você é sobrinha do Jacozinho? Peraí. Você é neta da dona Anita?!" E mudou o tratamento. A filha dele disse que ele tinha um retrato no consultório. Sabe aqueles que põem mãe, pai, madrinha? Ele tinha do titio.

\section{PAI, AVÔ E LUÍS CARLOS PRESTES}

O meu pai não tinha esse brilho, o vigor, o fulgor, a entrega para a vida.

2. Partido Comunista Brasileiro.
Ele não era comunista, mas foi entregar uns papéis que a minha mãe pediu e acabou preso. Diziam: "Fala, comunista!". E saiu como corajoso, porque 
não falou nada. Ele não sabia... O papai não tinha isso, ele não tinha essa surpresa... Ele não era surpresa, mas sempre o esperado. Acho muito chato brincar de coisas esperadas. Meu avô, do lado da mamãe, pouco conheci. Era abraçante! Trazia vestidos de organdi, era caixeiro-viajante, mas não sei o que ele vendia.

Cresci e vi o Prestes, algumas vezes, na minha casa. Das histórias que ouvia, quando era muito pequenininha, o primeiro som que me vem é a voz da minha mãe toda noite me puxando o cobertor e contando história para eu dormir gostoso e ter sonhos lindos. Eu era a Cinderela, que morava no palácio, e o príncipe era o Luís Carlos Prestes, que chegava num cavalo não sei de onde. O comunismo, que ela me explicava, era uma espécie de palácio para todo mundo.

A minha avó me contava, meio em iídiche, meio em português, histórias da infância dela. Só vim a entender quando vi o Chagall pela primeira vez; aquele mundo do rabino voando, os noivos voando, o cavalo indo ao contrário, poético, azul... Eu não entendia. Eu morava no Bom Retiro.

Foram duas casas fundamentalmente. A primeira, a da minha avó. Quando bebê e pequenina - a mamãe trabalhava -, eu ficava com a vovó o dia inteiro, muito feliz da vida. Depois morei anos em um apartamento parecendo muito, muito, com o prédio do filme $O$ ano que meus pais saíram de férias. É igualzinho. Mas nada tinha a menor importância, porque o prédio era na Prates com a José Paulino, e em frente tinha o Jardim da Luz, que era meu pátio, meu jardim, meu recreio. Era inteirinho para brincar. Nunca me faltou espaço para absolutamente nenhuma brincadeira. Quem era do Bom Retiro sabia que podia morar num lugar desse tamanhozinho porque tinha o Jardim da Luz.

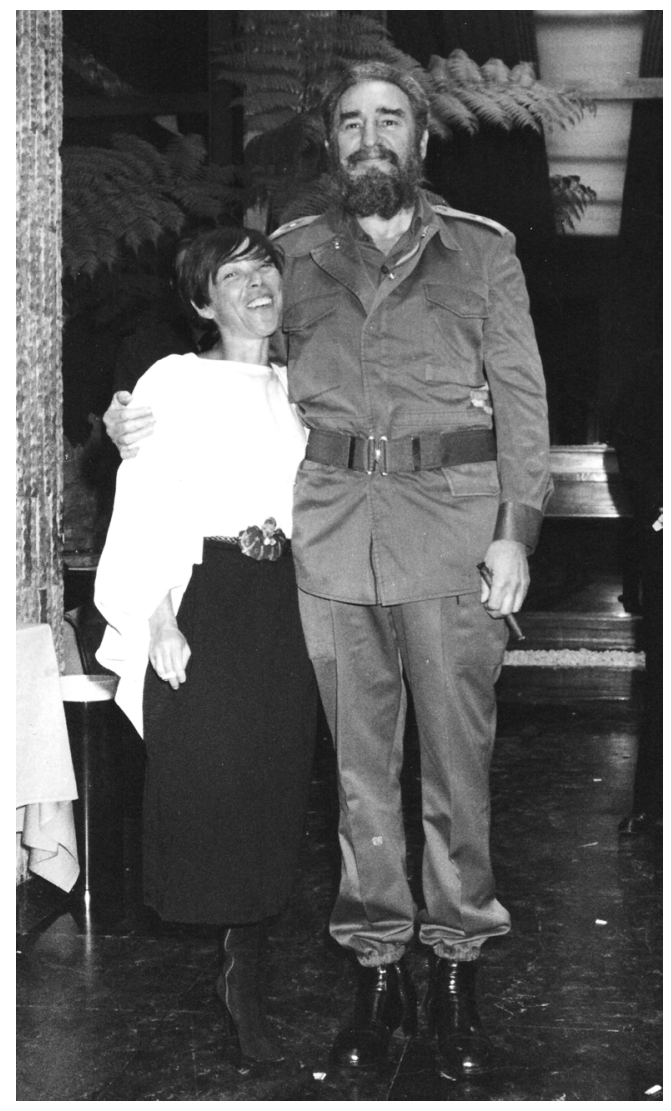

Com o amigo Fidel Castro.

\section{BOM RETIRO E INFÂNCIA}

O Bom Retiro está dentro de mim inteira. Não imagino a infância fora do Bom Retiro. O Jardim da Luz era só atravessar a rua, fazia parte da minha casa. Estudava longe, andava de bonde, sozinha, para ir ao Mackenzie. Com sete anos. Achava - não com esta palavra, porque não a conhecia - que a Estação 
comunicação \& educação • Ano XIV • Número 3 • set/dez 2009

da Luz era a fronteira onde se apresentava o passaporte. Para cá passavam os eleitos, os que moravam no Bom Retiro, e os outros eram os outros.

Então, o Jardim da Luz, meu Deus! Lá a gente pulava amarelinha, pulava caracol, brincava de cabra-cega, de lenço atrás, de a galinha do vizinho, de bicicleta, e eu caía sempre... Andava pelas trilhas. Era tudo maravilhento, muito bacana. E as campanhas do Partido, levava meio como brincadeira também. Com seis, sete anos, distribuía panfletos: "Vote em Matilde de Carvalho. A feirante do Partido". Não sabia nem o que estava fazendo, mas achava o máximo! Uma vez fui à frente duma passeata no lugar da menina magrela e esfomeada que não veio, e eu dizia: "Abaixo a carestia, estamos de barriga vazia". Quem fez isso não tem mais problemas com o ridículo. Nunca mais. Absolutamente...

Mas, no Bom Retiro, era tudo muito curioso: tinha o bar Jacó, onde ninguém ia fazer compras com dinheiro. Havia uma cadernetinha preta escrita em iídiche com os produtos que se comprava e tinha um número, que era o preço. A minha avó me mandava ir lá comprar. E aquelas barricas na porta vendiam pepino azedo, cebola não sei de onde - um cheiro! -, arenque, raiz forte. $\mathrm{E}$ as vilinhas, que de repente apareciam...

A gente ia nadar no Tietê, sozinha. Não no rio, mas no clube. E meu tio dizia: "Não precisa nada. Chega lá e diz que vocês são sobrinhas do tio". Eu achava que era a senha mágica: "Sou sobrinha do meu tio", e entrava. E a minha avó, uma pessoa com deficiência física, para mim era tão gigantesca, tão forte, que não me podia acontecer nada com ela em casa.

Quando fico vendo essas bobagens de inclusão, é de outro jeito, é com outra cabeça. Nunca me passou que o meu tio ou a minha avó tivessem deficiência, nunca. Porque era outro jeito de levar as coisas. Os negócios que a minha avó fazia... Tinha o verdureiro, que se chamava Salim, e fazia as compras para a vovó na quitanda, porque sabia escolher melhor. Tinha a dona Anita, dos ovos, uma senhora que vinha de trem de um lugar remoto, como Pirituba, e ia nos entregando ovo por ovo. Fora o que entrava de gente desconhecida na casa dela. Então, é muito difícil para quem cresceu desse jeito não estar aberta ao mundo. Não pode, não tem como! Por isso fico brava, desculpe, como educadora, quando vejo essas idiotices: "É preciso tirar a criança da rua". O que é isso?! A única função do educador é pôr a criança na rua, no mundo. A única que lhe cabe...

Brinquedo que sempre adorei, sou fascinada, alucinada, e onde acho, compro, é caleidoscópio; brinquedo de brincar sozinha. Sou alucinada por caleidoscópio. Sempre tinha em qualquer lugar, até em feirinha de praia. A imagem que nunca se repete...

Quando eu tinha 12, 13 anos, a minha casa era a sede de encontro para irmos ao cinema na cidade. O Ipiranga, o Marabá. A gente tinha um clubinho, I. L. Peretz, lá pelo lado do Ginásio Israelita Brasileiro Scholem Aleichem. Esse clubinho era das crianças judias progressistas. O lado judaico progressista que não aceitava Israel. Quando comecei neste Clubinho, acho que tinha uns 6 anos, eu era a tesoureira. Tinha uma caixa de sabonete Araxá e nela guardava o dinheiro das mensalidades; não sei qual era a moeda, mas tinha umas lá e carregava aquilo. Meu Deus, era um tesouro! Não sei muito bem o que 
achava que era, porque eu era do tamanho de nada. Tinha pingue-pongue, totó, campeonatos de alguma coisa, chamados esportes de judeu; nada de muito corporal, nada de fazer muito esforço, aquela coisa que não dá para suar. Encontrávamo-nos aos sábados, e esse clubinho também tinha colônia de férias, Kinderland ${ }^{3}$. Passávamos janeiro junto com as crianças do Rio de Janeiro; aí já um pouquinho mais velhos, claro, até 11, 12 anos. E durante o ano a gente se escrevia, trocava cartas. E líamos muito, muito! A gente disputava, e acho que foi só por isso que consegui acabar de ler Os miseráveis. Eram cartas com assuntos diferentes... A carta é muito legal. Era a carta com selo, não é essa besteira de e-mail! Mas não tem nem comparação: "beijos... bj”, sabe? Não, era carta mesmo! Trocava, ia levar ao correio, tinha remetente! Agora, quando recebo o pacote do correio, separo - deixo o que é mais curtido por último, e é o que vem manuscrito, letra manuscrita. Isso que vem com etiqueta não é nada!

No clubinho havia muita discussão de cinema, e me lembro que passou um filme com a Pierangeli ${ }^{4}$, que dá um beijo na boca e acha que ficou grávida! E aí todos nós entramos em pânico, e nem selinho a gente dava. Neste clubinho iam acontecendo as coisas, passava muito filme chinês ou russo, que não acabava nunca. Depois me desliguei, porque a gente cresce e os ritos de passagem nos levam para outro caminho.

Garoava, garoava sempre em São Paulo, era comum. Quando via aqueles "livros e brinquedos para os dias de chuva", tinha ataque epilético. Por que brinquedo para dia de chuva? Uma coisa muito maluca... Dia de sol não pode? Não precisa? Que maluquice é essa? Tinha um brinquedo da Melhoramentos que recortávamos umas figuras em preto, um príncipe, o bosque, e púnhamos um papel transparente atrás e uma vela. Chamava-se Teatro chinês. Ele era de sombras, era absolutamente mágico, mágico.

Quando eu estava no terceiro ano primário, a minha irmã foi para a escola e fomos para um colégio semi-interno, o Batista Brasileiro. Eu adorava o Batista. Então, o pastor tinha um cavalete no qual punha uma flanela; aí havia umas figurinhas recortadas, e ele punha ali e não caía! Chamava "flanelógrafo". Não era um truque, era mágica. Era realmente arrepiante.

\section{RÁDIO, LIVROS E HISTÓRIAS EM QUADRINHOS}

No apartamento em que morava com oito pessoas, e de dois quartos, almoçava ouvindo o Chico Alves. Que rádio seria? Nacional? Não sei. Cantava uma coisa - "criança feliz, feliz a cantar", alguma coisa assim. Ouvia rádio, muito, e tinha vitrola. Sempre tive vitrola. Livro e vitrola, sempre. Também, além de não saber como cabia tanta gente, não sabia como cabia tanto livro.

As histórias em quadrinhos, evidentemente, eram do império do mal, americanas, capitalistas, imperialistas; eu não podia ver uma coisa daquelas. Não preciso nem dizer que era proibido. Acontece que no cinema, na entrada, no domingo, havia pilhas de gibis usados, que podiam ser trocados. Eu não podia nem chegar perto... Cobiça, olho gordo, vontade, babação, promessas,
3. Colônia de férias situada no distrito de Sacra Família do Tinguá, no município de Engenheiro Paulo de Frontin-RJ, organizada desde a década de 1959 pela Associação Feminina Israelita Brasileira de Auxílio à Infância Vítima da Guerra - Vita Kemper, que posteriormente passou a chamar-se apenas AFIB. N.E.

4. Pier Angeli, nascida Anna Maria Pierangeli (Sardenha, 19 de junho de 1932 - Los Angeles, 10 de setembro de 1971), foi uma atriz italiana. N.E. 
comunicação \& educação • Ano XIV • Número 3 • set/dez 2009

xingamentos de tudo, até que Álvaro Moya - a pessoa que merece a minha gratidão eterna, e ainda hei de fazer essa homenagem; bendito seja! - fez um trabalho, um movimento, conferências explicando - ele era comunista - que quadrinhos não eram perigosos, não afetavam a cabeça, não transformavam ninguém em vassalo. E deu um alvará, uma bênção: toda criança podia ler gibi. Quer dizer, as crianças brasileiras, progressistas. Eu lia Tarzan e Mandrake. Flash Gordon tinha, mas não era o meu pedaço, e sempre tive aflição com ficção científica. Batman tinha, mas também não me encantava tanto. Eram muito mais a figura e a palavra, a rapidez... Não quero dar uma de semiótica, sabe, mas sair do parágrafo e encontrar aquela coisa trepidante, ágil, acontecente, era uma loucura! E me lembro de um que era até Disney, que ninguém lembra, que se chamava Esquálidus. Uma espécie de um ET, ele dormia no espaldar da cama. Ninguém lembra, não? Não é criação minha, mas ele se enroscava no espaldar da cama, uma maravilha! Tinha uma outra menina, Laura Jane. Ela falava: "Areia da grossa, areia da fina, areia, me faça ficar pequenina". Eu adorava! Era um Disney não idiota, não piegas, não passava por cima de tudo e acabava. Era um Disney preto e branco, umas coisas muito boas.

O que era muito legal é que havia dois cinemas no Bom Retiro. Eu levava a minha irmã. Lá em cima, na cabine, quando queriam projetar colorido, tinham papel celofane e botavam no visor: vermelho, verde e amarelo, e a tela ficava colorida. Era o máximo da tecnologia! Muito mais tarde apareceram os óculos de três dimensões. Bom, para entrar nesse cinema é claro que não custava muito, e tinha na porta um monte de gibi para trocar... era fantástico, porque era uma iniciação aos mistérios dos quadrinhos, uma atualização permanente. E tinha, também, pipoca americana grudenta e cor-de-rosa, um horror. Os dentistas punham aquilo na pipoca, porque todo mundo ia ao dentista no dia seguinte, uma coisa absurda. Os pais aproveitavam e dormiam. Toda criança ia sozinha com a irmã, com o irmão, e ficavam lá vendo aquilo, que não acabava mais, mas era fantástico. Flash Gordon era seriado, muito legal!

\section{BALÉ E PIANO}

Para toda menina judia, não tinha conversa: tivesse aptidão, talento, vontade, o mínimo de entusiasmo ou não, era obrigada a estudar piano, absolutamente obrigada; o menino, violino, nas mesmas condições, quisesse ou não quisesse. Passei por umas 12, 15 professoras de piano, odiando absolutamente todas por igual. Balé já cobiçava um pouco mais e passei brilhantemente - não tão brilhantemente -, mas, enfim, consegui galgar as escadarias da escola de balé do Teatro Municipal, que era embaixo do viaduto do Chá. Fui aluna do professor Michelle Barbano, depois passei por várias professoras, em vários lugares, porque comecei aulas em outras escolas. Mas estudei, e quando consegui mandar no que queria, aí sim fui dançar. Mas, pequenininha, foi um desencontro de possibilidades. Ah! Dancei até com a Eva Wilma. No Batista ela fez uma festa de fim de ano, montou o Quebra-nozes. Os meninos não tinham que aprender 
A única função do educador é pôr a criança na rua, no mundo • Fanny Abramovich

balé, aliás, aconselhavam que não quisessem. Eles ficavam, coitadinhos, tocando aquele violino de lascar. Na cultura judaica, faz parte da formação.

\section{LEITURAS}

Sábado, a gente ia passear com a mamãe na rua Barão de Itapetininga, e era o que havia de mais chique. Entrávamos num prédio quase de esquina e, no segundo andar, tinha a Livraria Pathernon, do senhor Álvaro Bittencourt, com milhares de livros. Olhando, mexendo, sentindo, cheirando... Eu era absolutamente maluca por aquilo, e ainda tinha a Brasiliense... Chegou uma hora que não tinha mais o que ler... em português . E fui estudar na União Cultural Brasil-Estados Unidos para poder ler. Havia umas coisas do Júlio Verne, e eram do meu pai. Ortografia antiga... Para comprar tinha muito pouca coisa. Tanto que, de repente, estava lendo o José Lins do Rego, aqueles meninos dele. São cinco volumes, que não eram para criança, nunca. E Capitães de Areia! Ia inventando o que dava, mas tive que aprender inglês, que não aprendi direito, e depois francês, que aprendi direito, para continuar lendo, lendo, lendo, lendo, lendo.

\section{REUNIÕES COMUNISTAS}

$\mathrm{Na}$ minha casa, vinham uns dirigentes do Partido fazer reunião e, nessa hora, eu tinha que ir para outro lugar. E tinha um passarinho, na gaiola da cozinha, e cada vez que esse dirigente falava qualquer coisa, o passarinho assoviava em cima e ninguém escutava nadinha. Era algum stalinista disfarçado e o passarinho sacou antes. A minha mãe foi candidata a vereadora. A mamãe foi a primeira mulher eleita, pelo que me contou o Bolívar Lamounier - não sou metida a saber de História. Só que o Partidão, óbvio, não era legal, e usava uma legendoca dessas de aluguel, PPM, PP, qualquer coisa. Ela foi cassada, acho que nem tomou posse. Ele me contou, ainda o Bolívar, que quem subiu no lugar dela, e que também usava uma legendoca de aluguel (?!), foi o sr. Jânio da Silva Quadros. Quer dizer, a história do País poderia ter sido diferente, sei lá.

\section{PROFESSORES INESQUECÍVEIS}

Naquela antologia que organizei, O meи professor inesquecível, todos escrevem sobre o seu professor marcante, porque ensinou isso, abriu a porta daquilo, não sei o quê. Só eu escrevi sobre uma professora que me aterrorizava, que para mim media três metros e meio, uma velha - talvez tivesse 18 anos, e eu tinha oito -, e me obrigava a saber de cor todas as bobagens do mundo: todas as estações onde parava o trem da Sorocabana, todos os afluentes da margem esquerda do Amazonas, que nunca veria na vida. Era esse o tipo de coisa importante que a dona Linda me ensinava, e percebi, lógico que não com oito 
comunicação \& educação • Ano XIV • Número 3 • set/dez 2009

anos, que ela foi minha professora inesquecível porque ficou como um modelo: não posso ser, nem de longe, parecida com a dona Linda. Tenho que procurar outro caminho, e consegui não ser dona Linda. Isso é uma vitória! Poucos professores tiveram proposta de parceria feita por ex-aluno do pré-primário, como eu tive do Marcelo Cipis. Escrever uma história para ele ilustrar!!! Uma história como as que eu contava para ele, quando era pequenino.... Isso é que é honra, o resto é batata frita.

\section{LOBATO}

Virei brasileira por Lobato; antes, era só do Bom Retiro. O Lobato me apresentou ao Brasil, e o Teotônio me fez acordar para a urgência em termos de Brasil. Não reli mais os livros didáticos dele, os ensinantes, porque nunca gostei de nada disso, mas me parece que assim mesmo são bem melhores e bem menos idiotas do que os que fazem hoje... não vou garantir. Petróleo também nunca reli, mas as Memórias da Emília realmente adoro, e A chave do tamanho. A reforma da natureza realmente é um deleite, uma risada, um inesperado. E acho que desejei ser duas coisas na minha vida. A primeira, chacrete - mesmo que não tivesse condições, pela minha altura, mas porque, é lógico, eu adorava o Chacrinha. Às vezes pegava o ônibus Cometa para o Rio só para assistir ao programa dele! Ele buzinava para mim e falava: "Aquela menina que sabe tudo, Teresinha!!". Uma maravilha, uma maravilha!!! E depois, desejei ser a Emília... um pouco da Emília consigo ter. Mas não ainda para entrar num auditório e dizer: "Eu sou Independência ou Morte"; ainda não tanto. Quando pego esses livros, eles veem com o cheiro da minha casa, o cheiro da minha infância... aquele papel grosso, a poeira, o fogão vermelho da minha avó, que ela ganhou sei lá de quem. Sabe, volta tudo.

5. Tatiana Belinky já realizou um Depoimento para a revista Comunicação \& Educação. Ver: BELINKY, T. Uma amadora, do verbo amar... Paixão! Comunicação \& Educação, Brasil, v. 10 n. 2, 2008. Disponíve em <http://www.revistas. univerciencia.org/index. $\mathrm{php/comeduc/article/}$ view/5141/4768>. Acesso em: 25 jul. 2009. N.E.

\section{TATIANA BELINKY}

A Tatiana $^{5}$ e a minha mãe eram muito amigas. Não sei exatamente quando conheci a Tatiana, mas ela faz parte da minha vida desde sempre, não desde nenê, mas desde sempre. Como eu trabalhava quando fui fazer cursinho, o marido dela, o Júlio, resolveu me chamar para ser bibliotecária dele, arrumar a biblioteca e me pagar para isso. Era uma bolsa, mesada, que estava me dando para poder fazer o cursinho em paz. Demorei para descobrir, mas é óbvio. Nem mãe e pai fariam uma coisa dessas, me chamando para ser bibliotecária. Convite simplesmente irresistível, não tinha o que pensar. Mas o que mais me impressionava na Tatiana, sempre, e que não posso esquecer, era sua segurança: no escritório dela tinha aquela maquininha de datilografia e, aberto, marcado com lápis, o capítulo, o parágrafo, dois parágrafos, que virariam o script do dia seguinte, do Monteiro Lobato, ou das Fábulas Animadas, ou de qualquer coisa. Ela lia, não anotava nada e batia direto no estêncil, que não se enxerga, é branco no branco. Para mim, qualquer demonstração de segurança a partir daí é ridícula, porque nunca vi ninguém tão seguro. Não dava nem para reler, 
para fazer cópia naquilo. A Tatiana foi a pessoa, na minha vida inteira, mais próxima de Diderot que conheci.

Fora isso, ela era grande amiga. Era amiga da minha mãe, era admiradora, devota da minha avó, como todo mundo foi. A mamãe ficou muito doente, e quando a enterrei, dois dias após fui direto para a casa dela. Depois fiquei com um pouco de vergonha na cara; o Júlio era psiquiatra, não dava para ser tão escancarada. Penso que a Tatiana acha que sou a filha que ela não teve e que segue os passos dela. Porque na época da minha mãe eu dava aula; na época dela, dei de escrever. Pode ser? Pode muito bem ser.

\section{EDITORA GIROFLÉ}

A Giroflé foi uma das primeiras editoras a fazer livros retangulares, belíssimos... projetos do Fernando Lemos. Eu era a orientadora pedagógica. A editora pertencia a três portugueses: Sidónio Muralha, Fernando Lemos e Fernando Correia. Eles tinham uma proposta... E isso nos anos 1960, e são vanguarda até hoje. Uma loucura aquilo! Quer dizer, mais vanguarda visual, digamos. O projeto era deslumbrante... os intelectuais, professores, apoiadores pagariam " $\mathrm{x}$ " por mês para ser associados. Essa era a diferença, e o que poderia sustentá-lo, mas não o sustentou, claro! Não conseguiram.

Então, fui orientadora pedagógica da Giroflé, fui orientadora do teatro infantil do Teatro de Arena. Pensa bem: isso em 1960, quando eu nem era formada e já estava querendo sair da sala de aula... Sabia que tinha outro pedaço que devia ter um olhar mais atento, sem ser didático. Acho que fiquei na Giroflé até acabar... não lembro.

Quando entrei na faculdade, na USP, vinha de uma liderança secundarista braba. E a mamãe me perguntou se já estava militando na base do PC. Falei assim: "Não, mamãe, estou sendo disputada por outros grupos". Foi uma das poucas coisas que ela me mandou na vida: "Não eduquei filha minha para não ser militante do PC. Você tem uma semana para achar a base do PC". Fui e achei. Aí fui dirigente do movimento universitário até o fim.

E só para fechar bonito, me lembrei agora: a minha casa era na rua Prates, 155. Em 1964, recebi todo mundo

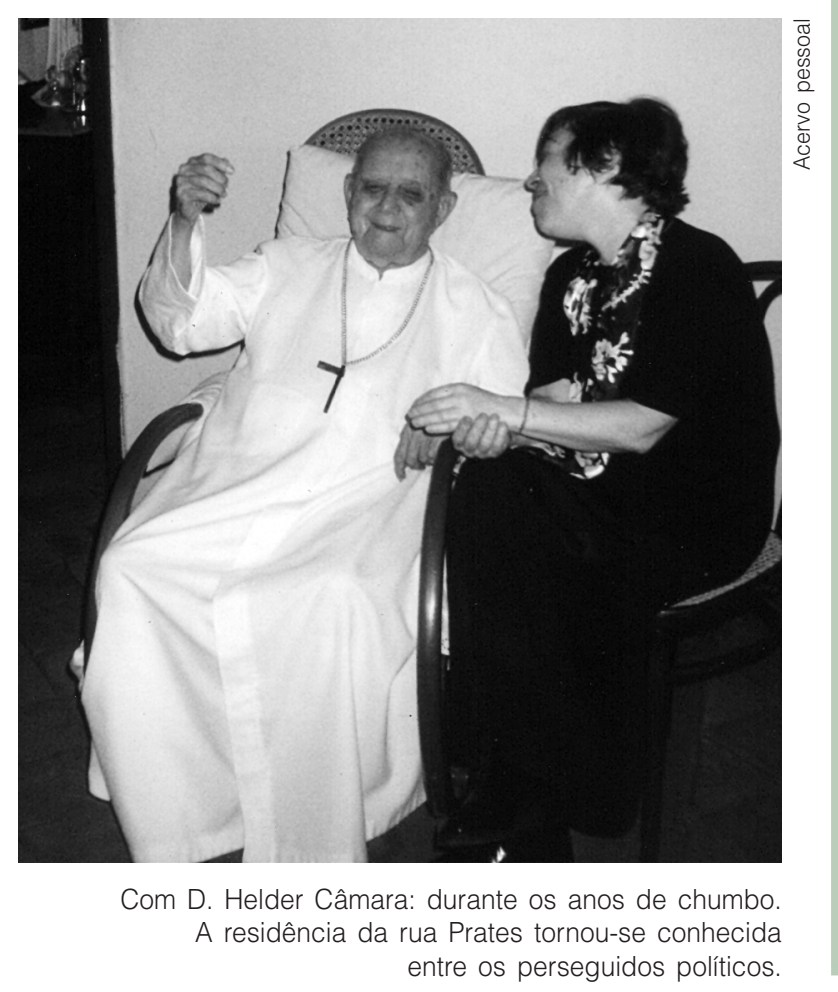


comunicação \& educação • Ano XIV • Número 3 • set/dez 2009

da Bahia, os perseguidos. O Capinam foi morar com meu avô Luis Lamego, e coloquei-o na Giroflé, como office-boy. O Gil não precisou de ajuda, porque fui recebê-lo e ele já tinha emprego na Gessy Lever. E anos depois encontrei o Tenório, um psiquiatra conhecido, que mora aqui em São Paulo, mas veio da Bahia. Ele estava com não sei quem e alguém deve ter dito: "Ela é a Fanny". "Você que é a Fanny, rua Prates, 155?! Telefone...361100?" Esse era o endereço seguro, que corria na Bahia.

\section{PARIS}

Quando mamãe morreu, em 1964, pensei: "Vou ter que sair dessa rápido, porque senão vai entrar o jogo das capitanias hereditárias, e não vou ser a minha mãe". Pedi uma bolsa de estudos para Paris. Fiquei lá um ano e meio fazendo nada, porque ninguém entendia o que fui fazer. Não fui fazer uma tese, então era muito complicado para eles. Não fui fazer pós-graduação... mais complicado ainda. Andava por Paris, me perdia pelas ruas, ia ao cinema toda tarde, ia ao teatro toda noite. Bom, eu fiz arte. Fui para a Itália, inventei uma bolsa de televisão, na RAI, tele-escola.

Sou muito lúdica, hedonista, me faço perguntas sobre determinado ciclo que estou vivendo, e, quando já respondi bem respondido, chega, porque não vou ficar me fazendo as mesmas perguntas a vida inteira. Então vi que a pré-escola já não tinha mais nada para me perguntar. Sabia que não voltaria para lá... E pensar que a professora que ficou me substituindo estava em pânico. Achou que perderia o posto quando eu voltasse! Fui trabalhar direto com crianças da primeira à quarta série, em teatro e artes plásticas, que era o que estava procurando. Depois abri a escolinha ${ }^{6}$ e fiquei um tempo buscando outras respostas e desencadeando novas perguntas.

\section{ESTREIA NA LITERATURA}

O meu primeiro livro pedagógico é o Teatricina, que não existe mais nem por decreto. É o registro da escolinha. Isso em 1979, alguma coisa assim, e foi publicado pela Funarte. Mas não se acha nem em sebos. Fiz esse primeiro livro porque tinha que deixar um registro da escolinha, que foi uma experiência rica e bonita demais. Fechei a escolinha porque faliu, quebrou economicamente. Tanto berrei que arte tinha que ser incluída no currículo, que ela foi, mas aí não tinha mais alunos. Dois economistas, pais de alunos, vieram fazer as contas, dízima periódica, PI e raiz quadrada, mas não dava mais, não tinha mais jeito.

Fiquei anos pagando as dívidas e não podia fechar sem deixar anotações

6. Trata-se do Centro de Educação e Arte - CEA Maiores detalhes sobre o CEA podem ser encontrados em ABRAMOVICH, Fanny. Ziguezagues: andanças de uma educadora e escritora. São Paulo: Editora Atual, 1996. sublinhadas. Mas naquela época jurava de mãos e pés juntos que não sabia escrever. Jurava não, tinha certeza. Não sabia nem como faria esse livro, e as professoras da escolinha, que estavam tentando comigo, sabiam muito menos. Um dia me deu um insight, quando peguei um remédio em cima da geladeira da casa que a gente estava, e vi que podia fazer em forma de bula. Jogos como 
instruções de bula e sem precisão de escrever mais nada. Um pouco do que se acreditava na escolinha, o eixo norteador, foi resolvido com uma entrevista feita pelo Wladimir Soares, jornalista do Jornal da Tarde, muito meu amigo. Teatricina ficou demais da conta!!!

Só descobri que sabia escrever quando me iniciei no jornal. Muito tempo depois de fechar a escolinha, dava cursos pelo Brasil inteiro em cima do que tinha feito com as crianças. $\mathrm{O}$ que elas acharam chato, aborrecido, idiota, foi para o lixo; o que elas consideraram interessante, legal, divertido, ficou. Andei de cima para baixo e fui jurada de concursos disso e daquilo. Em um desses concursos de dramaturgia infantil, já estava enlouquecida, me perguntando: Por que só eu mereço ler tanta bobagem?! Por que, entre tantos seres na terra, fui a escolhida para ler aqueles desatinos todos?! E mal escritos...! Não tendo o que fazer, uma noite montei um artiguinho sobre a minha perplexidade, ira, ímpetos assassinos etc., em relação a tudo aquilo. Deixei com o Wlady e fui embora para algum lugar, fui descansar em um hotel. Quando voltei, ó, surprise! Estava impresso, editado no Jornal da Tarde! Quase morri.

O Wlady trabalhava lá, era crítico de música. Recebi o recado de que o Mauricio Kubrusly, que era o editor de variedades na época, mandou me chamar. Gostaria que eu escrevesse. Fiz pautas ligadas a alguma coisa que não existia ainda, estava nebuloso, ligadas à produção cultural para crianças: literatura, discos. Ele escolheu literatura e fui para casa começar a procurar sobre livros para crianças. Cortei, cortei e cortei, e assim mesmo saiu uma matéria de página dupla, e pus bibliografia. Aplaudidíssima. Ele me pediu outras; fui escrevendo, as matérias fazendo sucesso, pois entro com o meu deboche, o que era um pouco inusitado. E nisso fui descobrindo que estava fazendo a crítica da produção cultural para criança; aí me ofereceram uma coluna para criança e comecei a fazer. Uma coisa novésima: dei voz para a criança, entrevistava-as... Inventei uma coisa superlegal, porque falava com a criança pelo telefone, então, não tinha barreira nenhuma. Tinha criança que marcava encontro comigo na padaria, um barato! Estava protegida, ela podia dizer o que quisesse. Eu falava sobre brinquedo, música, quer dizer, disco, teatro, essas coisas que eles estão inventando agora, mas só que isso em 1970, e foi muito legal. E um belo dia eles tiraram a minha coluna. Sem mais nem menos. Não tiraram, mas queriam que eu continuasse só fazendo a crítica de literatura infantil. Fiquei furiosa, decepcionada. Demorei a desentristecer... Mas a mesma crítica eu levei para os lugares onde fui convidada a falar para crianças.

\section{OUTROS LIVROS}

Aí foi $O$ estranho mundo que se mostra às crianças. Os artigos já tinham saído, tinham gostado, e eu não tinha ainda uma exigência de linguagem. As pessoas gostaram, demorei um pouco para elaborar, e um pouco antes saiu a antologia $O$ sadismo da nossa infância, que também foi uma sacada de ideia, mas a realização foi pífia. Saiu no mesmo ano, mas um pouquinho antes. Depois 
comunicação \& educação • Ano XIV • Número 3 • set/dez 2009

veio o Quem educa quem?, já mais trabalhado. Alguma coisa era do jornal e boa parte feita especialmente. Aí saiu Mito da infância feliz, que era muito bonito, uma proposta menos anarquizada, e saiu também os Ritos de passagem da nossa infância e da nossa adolescência, mas mesmo assim não foi a penetração para discussão com professoras que imaginei que seria: não aconteceu, não chegou, não sei se por erro meu de escolha dos autores, se por falta de marketing... Por alguma coisa, não aconteceu. E o Quem educa quem estourou. O livro era muito bom, muito engraçado. Não era uma apologia, mas um encantamento com o autodidata. Algo não explícito, mas para mim era um elogio à minha mãe. Não precisava estar explícito, mas ela foi autodidata. Combinei isso com aquilo, com os autodidatas do País, coisas bonitas. Juntei entrevistas com um mestre dos grandes mestres, perguntando dos grandes professores. Quem foi o grande professor do Paulo Freire, do Antonio Candido, mudando as óticas. Foi um livro que mexeu, e até hoje ele é falado.

A Scipione me procurou para pedir um livro de arte e educação, e falei: "Chega, esse ciclo também está encerrado! Se quiserem, faço sobre literatura infantil”. E o livro saiu em 1989. Daí me centrei, estudei muito - já vinha trabalhando, mas de maneira dispersa -, aí alinhavei, costurei, e quando fui, digamos, didatizar da minha maneira cutucante, para o professor, pude passar para eles as minhas prioridades da literatura infantil: Gostosuras e bobices.

O Espelho, espelho meu aconteceu assim: um belo dia chegou uma moça em casa, não me lembro o nome... Teresinha? Uma coisa assim. Ela estava começando uma coleção nova, na Brasiliense, faz muito tempo - Caio Graco ainda era vivo -, chamada Preto no Branco. E ela me disse que estava convidando só jornalistas para escrever uma história, de 30 laudas. Ela tinha convidado o Ruy Castro, o Gilberto Mansur, não sei mais quem, mas não tinha nenhuma mulher; então ela veio me convidar. Da total descrença em dar conta de escrever até a entrega do original, deu 30 dias! Um mês, e escrevi meu primeiro livro de ficção para jovens!

Não vou conseguir falar numa sequência cronológica, mas, de qualquer maneira, o Também quero pra mim foi o primeiro livro para criança, e saiu pela editora Studio Nobel. Quem coordenava essa coleção era o Ricardo Azevedo, e ele me pediu para escrever um livro para criança. Quem ilustrou foi o Alcy Linares, que tinha ilustrado o meu primeiro juvenil da Ática. Também quero pra mim é um livro singelo, sobre as invejinhas que todo mundo tem... Foi surpreendentemente fácil, não esperava. Um livro para criança pequena. Também, nunca mais fiz para criança tão pequena, para criancinha mesmo, sete anos, do primeiro ano do primário. Eu curti. Foi um desafio, me pegou de susto, me pegou de surpresa. Quando fui escrever o primeiro juvenil para a Ática, fui paquerada direto pelo Fernando Paixão - altas paqueras literárias, evidentemente. Quando levei o texto, quem o recebeu foi a Carmem Lúcia. Ela olhou para mim e falou baixinho: "Não temos o costume de receber textos dessa qualidade”. Fiquei roxa. É um texto que, desculpe a pretensão, mas, quem gosta de cinema, é como se a câmera mudasse de lugar e nada mais acontece 
daquele jeito, dependia de onde você estava, onde estava a câmera, e qual era o foco. E me deu muito prazer. Foi ilustrado por Alcy Linares, e deu muito certo. Porque tem a ver com o humor, é leve. Para meu impacto, surpresa, susto e espanto total, Cruzando caminhos virou objeto de tese $\mathrm{e}^{7}$. Parece que a moçada gostou, porque escrevo em gíria, invento palavras, e há histórias que não são completamente abobadas. Enfim, é um livro do qual eu gosto.

Um outro livro juvenil, Que raio de professora sou eu?, saiu pela Scipione. Eles me chamaram, eu tinha feito Gostosuras e bobices, e me pediram um texto para a 7 $7^{\mathrm{a}}, 8^{\mathrm{a}}$ série. Propus um caderno de anotações, daqueles que todo mundo tem ou tinha. E Que raio de professora sou eu? virou até peça de teatro no Rio Grande do Sul. Muito legal! Gosto muito do título. Um livro que já tem anos, deve ter uns quinze anos pelo menos, e ainda continua se perguntando que raio de professora sou eu. O incrível é que esse livro - pasmem - está traduzido para o tailandês.

Vou falar de Sylvia sempre surpreendente, que é um livro especial do meu coração. A Sylvia Orthof foi uma grande, grande escritora para crianças, em minha opinião. Depois do Lobato, a figura mais importante da literatura infantil brasileira foi ela. Nós fomos muito, muito amigas... Assim, amigas e irmãs. E ela morreu faz doze anos, mas, quando fez dez anos, achei que devia escrever alguma coisa para ela. Eu sabia de quinhentas histórias da Sylvia, e pedi ao Gê, filho dela e artista plástico, para ilustrar, e ele topou. As Irmãs Paulinas editaram. Montei o livro em quatro atos, porque a Sylvia era uma pessoa de teatro. E cada ato tem o nome de um livro dela. E aí no final, tem o programa do espetáculo, com um monte de coisas, inclusive com os 18 melhores livros dela, porque 18 é o número da vida para nós judeus. Então não pus nem 10, nem 20; pus 18, os 18 melhores livros.

O Espantoso não conta de espantos de terror, de lobisomens, nem de mula sem cabeça, nem de nada disso. É de espanto com situações, não vou dizer cotidianas, mas situações próximas, com as quais ficamos espantados. Então esse espanto, um deles, por exemplo, o primeiro beijo de língua, que a gente espera, sonha, delira, morre de medo, de expectativa, e daí é aquela lambuzação. Você não sabe onde errou, e o que aconteceu para ficar aquilo. Esse tipo de espanto. Quem ilustrou - eu pedi - foi a Mariana Massarani. Adoro o desenho dela, adoro, sempre quis ser ilustrada por ela. Não a conheço, mas imagino que seja a cara desse desenho.

E agora, só para terminar, o De surpresa em surpresa é um livro que existe há certo tempo, e já teve algumas edições. A última era um espanto de feia. E agora a Saraiva refez, revestiu. Eu tinha pedido e eles me atenderam: quem ilustrou foi um ex-aluno meu de criancinha, o Márcio Levyman, que entendia o que eu queria. Conta a história de uma menina que vai pela primeira vez ao teatro; então, a deslumbrância, a taquicardia de chegar ao teatro, ao Municipal, e ver o corredor, o corrimão, o teto, o tapete, a maçaneta, o banheiro, aquela imensidão, a escadaria, enfim... Deslumbrância toda. E depois, naquele teatro maravilhoso e único, vai passar um teatro de bonecos, e a coisa é tão linda, tão
7. Ver: MAGRO, Maria Valquíria. Caminhos cruzados de Fanny Abramovich: a recepção da narrativa pelo leitor jovem. 2007. $98 \mathrm{f}$. Dissertação (Mestrado em Letras)-Universidade Estadual de Maringá, Paraná, 2007. 


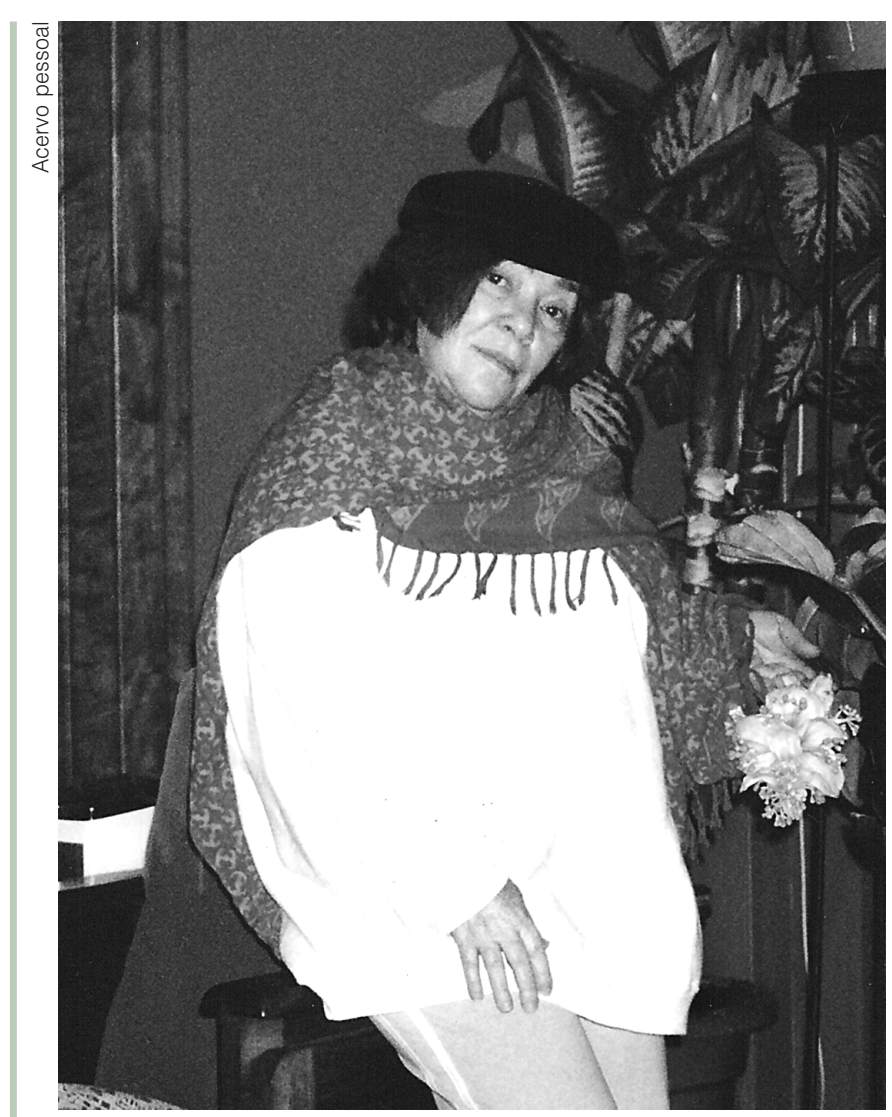

Em 2009, a professora, jornalista e escritora comemorou 20 anos de carreira dedicados à literatura infantojuvenil. linda, tão linda, que o Márcio, que brincou muito de teatro de bonecos comigo quando era pequeno, criou um trabalho de ilustração e interatividade para o leitor que é uma coisa absolutamente deslumbrante.

O livro As voltas do meu coração é bonito mesmo! Foi o terceiro livro juvenil que escrevi. A primeira edição tinha a capa e as ilustrações feitas pelo Ricardo Azevedo, muito bonitas, mas eram pesadas, mais por causa do cerceamento de 1968. Depois, na segunda edição, quem desenhou foi o Paulo Bernardo, que viveu tudo aquilo e não ficou tão impressionado; então, ficou uma coisa mais leve. Eu ia escrever a história de uma pessoa, uma mocinha com

dois namorados, e virou completamente outra coisa, por conta do nome mesmo da personagem. Os dois namorados existem no começo, mas vão perdendo a importância, o fôlego, a intenção. Então foi acontecendo uma puxada histórica e, de uma coisa que ia ser uma aventurinha amorosa inconsequente, realmente mergulhei fundo, em uma pesquisa de determinados acontecimentos da época, alguns que estive presente, lógico. Até porque, 1968 foi tão libertador no mundo inteiro, aconteceram tantas coisas ao mesmo tempo, que também o político era fundamental; mas no pessoal havia tantas facetas libertadoras, que tudo se misturava. E tudo fica como época de grande libertação mesmo. É um livro que me deixa muito contente, porque é a trajetória, não minha nem de uma pessoa, mas de gerações, de procuras. Fico muito dignificada, contente, por ter nascido numa época em que a gente acreditava. E quem teve a bênção de ser jovem em 1968 acreditou... Era uma época em que a gente ousava acreditar. 